\title{
Dynamics of suspended sediment concentration and the impact on a lake-inhabiting bivalve (Corbicula japonica) in the Abashiri River basin, Hokkaido, northern Japan
}

\author{
S. Yanai ${ }^{1}$, Y. Nishihama ${ }^{2} \&$ R. Tamura ${ }^{3}$ \\ ${ }^{1}$ Hokkaido Institute of Technology, Japan \\ ${ }^{2}$ Tokyo University of Agriculture, Japan \\ ${ }^{3}$ Hokkaido Fish Hatchery, Japan
}

\begin{abstract}
The dynamics of suspended sediment and the impact on a lake-inhabiting bivalve were studied in the Abashiri River basin, in eastern Hokkaido, northern Japan. The Japanese bivalve: Corbicula japonica is the most important fishery resource in Abashiri Lake. Torrential rain over $80 \mathrm{~mm}$ per day resulted in considerable sediment concentration during the summer of 2003. Suspended sediment (SS) concentrations $>1600 \mathrm{mg} / \mathrm{l}$ were measured in the tributaries, where fragile rock formations and faults had developed. The factors influencing SS concentration were analyzed by multiple regression analysis. This led to the identification of soft bedrock and fault densities as significant factors influencing sediment concentration. Fine-sediment particles less than $0.063 \mathrm{~mm}$ in diameter accounted for more than $80 \%$ of the samples at all stations. Since the lake bivalve prefers coarse substrates, a negative relationship was observed between the percent of fine sediment and the C. japonica distribution and fatness. The substrate around the mouth of the river was also composed of fine sediment, which indicated that the suspended sediment produced from the mountain tributaries has deteriorated the lake environment, especially for $C$. japonica survival and growth.

Keywords: suspended sediment, Abashiri River, substrate, Corbicula japonica and watershed management.
\end{abstract}




\section{Introduction}

Anthropogenic activities such as urbanization and agriculture alter water infiltration rate and storage capacity and, hence, susceptibility to soil erosion. These effects result in changes in run-off and sediment routing within watersheds [16]. Hokkaido, the most northerly island in Japan, has been subject to increasing human exploitation since the early 20th century. Land use has expanded dramatically, with concomitantly increasing concern about environmental degradation. The fine sediments produced in headwater areas flow downstream, eventually reaching river mouths, which may damage numerous fishery-based resources [11]. Despite increasing public awareness of the linkage between forest and ocean, there have been few studies on the ecological impacts of agriculture and deforestation on aquatic biota [10].

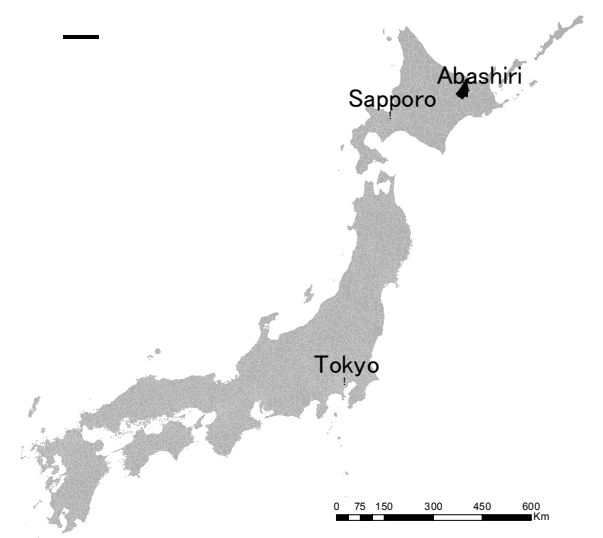

Figure 1: Location of the study watershed.

Here, we focus on a lake watershed (a relatively closed system in comparison with coastal watersheds, in which the terrestrial impact is felt primarily by fish populations). We first measured suspended sediment concentrations in rivers and lakes over the whole watershed, and we discuss determinants of sediment production. Subsequently, we observed the distribution and fatness of a lakeinhabiting bivalve. We consider bivalves to be good indicators of environmental impact, because they are largely sedentary and unable to escape the effects of environmental degradation.

\section{Study site}

The Abashirti River basin is located in western Hokkaido, has an area of $1380 \mathrm{~km}^{2}$, a channel length of $115 \mathrm{~km}$, and drains into Lake Abashiri (Fig.1). This is a lagoon lake with a surface area of $32.3 \mathrm{~km}^{2}$, a maximum depth of 16.1 $\mathrm{m}$ and mean depth of $6.1 \mathrm{~m}$. The fishery resource species in the lake are Corbicula japonica, Hypomesus nipponensis and Salangichthys microdon. The 
salinity in surface water ranges from 1.0 to 3.5 PSU between May and December. A large portion of the lake is anoxic below a depth of $5 \mathrm{~m}$. The Abashiri River flows into the lake on the south shore, and out of the lake northwards into the Sea of Okhotsk. The lower and middle reaches of the basin are cultivated for potato, wheat and beet, while coniferous forests cover the upper reaches.

The western portion of the watershed has fragile sedimentary rock, whereas volcanic pyroclastic flow deposits are found in eastern regions, forming a plateau along the middle reach of the river. Numerous landslide scars have been observed in eastern parts of the watershed.

The annual mean precipitation is around $800 \mathrm{~mm}$, with snow cover from November to April. Snow melt usually occurs from early April to mid May. Heavy rainfall sometimes occurs during summers, and daily precipitation may exceed $100 \mathrm{~mm}$.

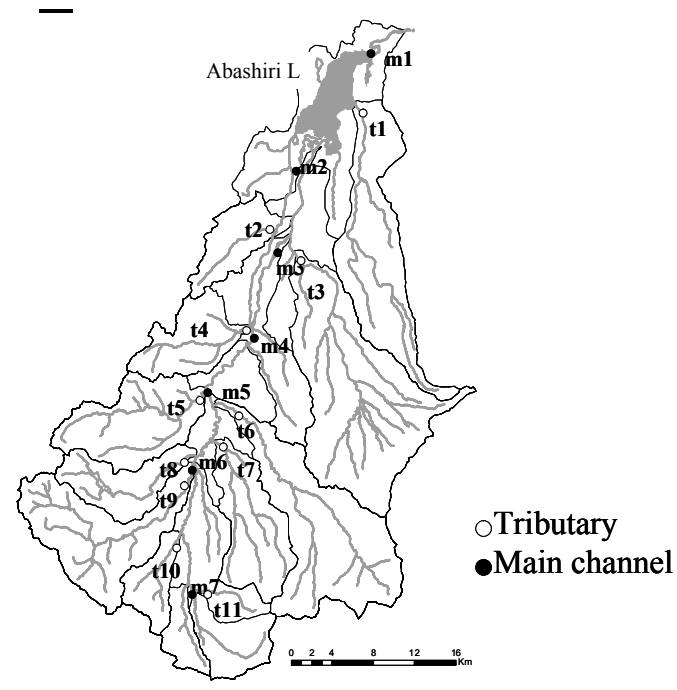

Figure 2: Water sample collection points.

\section{Method}

\subsection{Sample collection}

Seven water collection stations were established along the main river channel (St.m1 m7), and 11 stations were established at the mouths of tributaries (St. t1 t11) (Fig.2). Samples were collected by the Abashiri Watershed Environment Protection Board during downpours in spring, summer and autumn from 2003 to 2005. Bivalves were collected with scooping net and bottom sediments were 
collected with a Smith-McIntyre mud sampler $\left(0.05 \mathrm{~m}^{2}\right)$ at depths of 3.0 at 50 stations along the lake margins.

\subsection{Sample analysis}

Suspended sediment concentration in water samples was determined by percolation through glass fiber filters $(0.5 \mu \mathrm{m}$ mesh). The percolated samples were dried at $50^{\circ} \mathrm{C}$ for $48 \mathrm{~h}$ and weighed, then combusted at $550^{\circ} \mathrm{C}$ in a muffle furnace for determination of organic dry weight (percent of ash free dry mass).

Sizes of particles included in water samples were analyzed using two methods:

1. particles larger than $0.063 \mathrm{~mm}$ were separated out in sieves with different mesh sizes, then dried at $60^{\circ} \mathrm{C}$ for $24 \mathrm{~h}$;

2. smaller particles than $0.063 \mathrm{~mm}$ were analyzed with a particle analyzer (CAPA-300 Horiba).

Bottom sediments were treated in the same way as suspended sediments.

The $C$. japonica specimens collected in the sampler were counted, and the density per square meter was calculated. The width, height and length of each shell were measured with vernier calipers (Mitutoya, CD-20GM). Each soft tissue was dried and weighed. The condition of the animals was calculated as a dry weight per volume index (x 1000).

\subsection{Spatial analysis by Geographical Information Systems}

Land use on each tributary was measured using digital land use maps supplied by the national Ministry of Land Infrastructure and Transportation. Environmental factors, such as forest coverage, agricultural land, lithological hardness, slope gradient, and fault densities were also measured from these maps using GIS software (TNTmips ver.6.8, ESRI Arc View 3.2a and Spatial analyst).

\section{Results}

\subsection{Suspended sediment concentrations in spring and summer}

During the study period, we collected water samples in August 2003, April 2004 and April 2005. There were no large discharges in the summer of 2004. The highest concentrations of suspended sediment were observed in August 2003. Figure 2 shows the discharge during downpours in that month. This discharge was induced by torrential rainfall exceeding $79 \mathrm{~mm}$ on August 9-10. Sampling was carried out during peak, regression and normal discharges (Fig.3).

Suspended sediment concentrations at all stations along the main channel, except at St. $\mathrm{m} 1$ and $\mathrm{m} 7$, were higher than $1600 \mathrm{mg} / \mathrm{l}$, and the tributaries draining from the left bank transported sediment at even higher concentrations. These values declined remarkably with time to $<50 \mathrm{mg} / \mathrm{l}$ at all sampling stations after ten days (Fig.4). Most of the sediment was inorganic [ $>80 \%$ except at St.m1 (uppermost headwater) and St.m7 (downstream from the lake)]. 


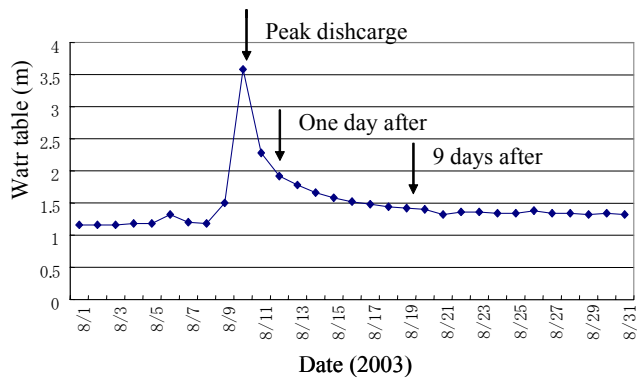

Figure 3: $\quad$ Discharge at August 2003.
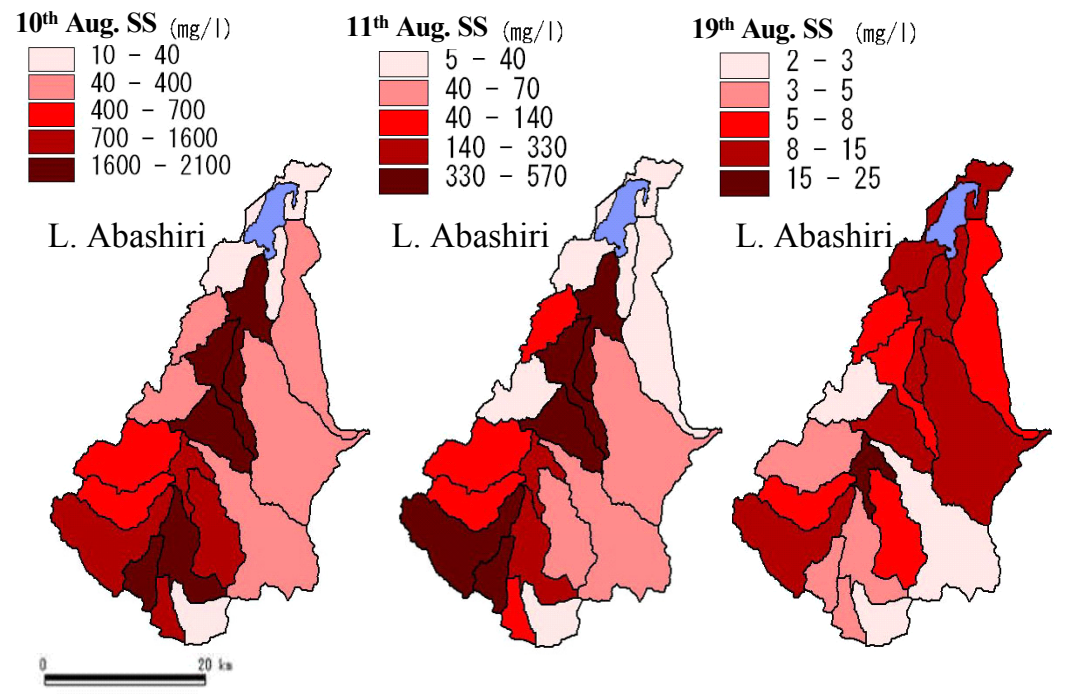

Figure 4: $\quad$ SS concentrations observed in Aug. 2003.

\subsection{Particle analysis}

Particle distribution in the suspended sediments did not differ significantly between the main channel and tributaries. Finer particles, less than $10 \mu \mathrm{m}$, comprised $40 \%$ of all samples, followed in abundance by medium sized particles between $10 \mu \mathrm{m}$ and $0.063 \mathrm{~mm}$. Coarser particles usually comprised $<10 \%$ of all samples.

\subsection{Bottom sediment and $C$. japonica in the lake}

Bottom sediments were collected at three depths, at 50 stations around the lake. Fig. 6 shows the percentage of fine particles $<0.063 \mathrm{~mm}$ at each sampling station. Fine particles were more abundant on the southern shore where the river flowed in, and on the northern shore where the river flowed out. The percent of finer sediments tended to increase with water depth. 


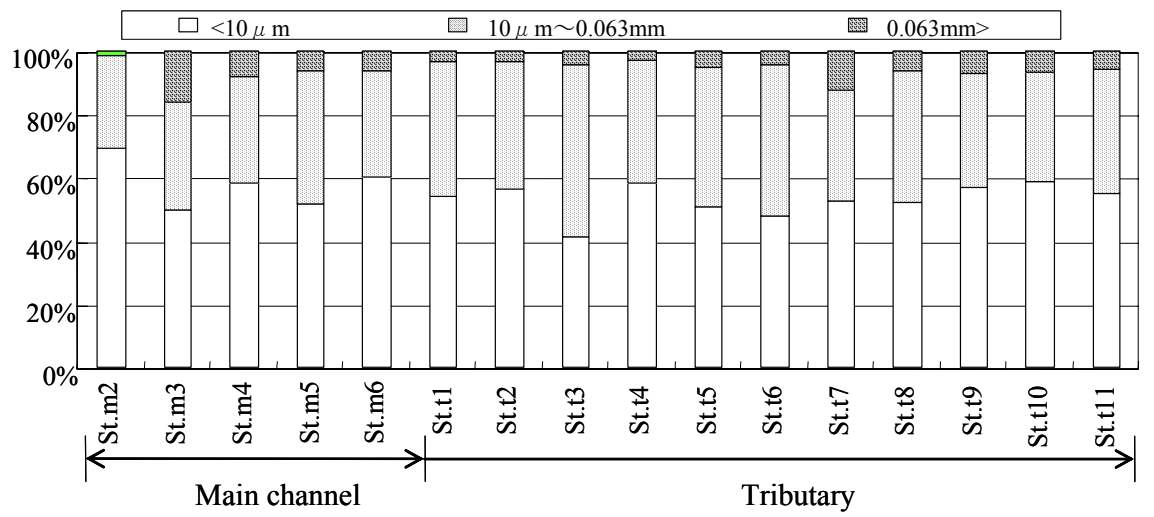

Figure 5: $\quad$ Particle distribution in suspended sediment at the all stations.

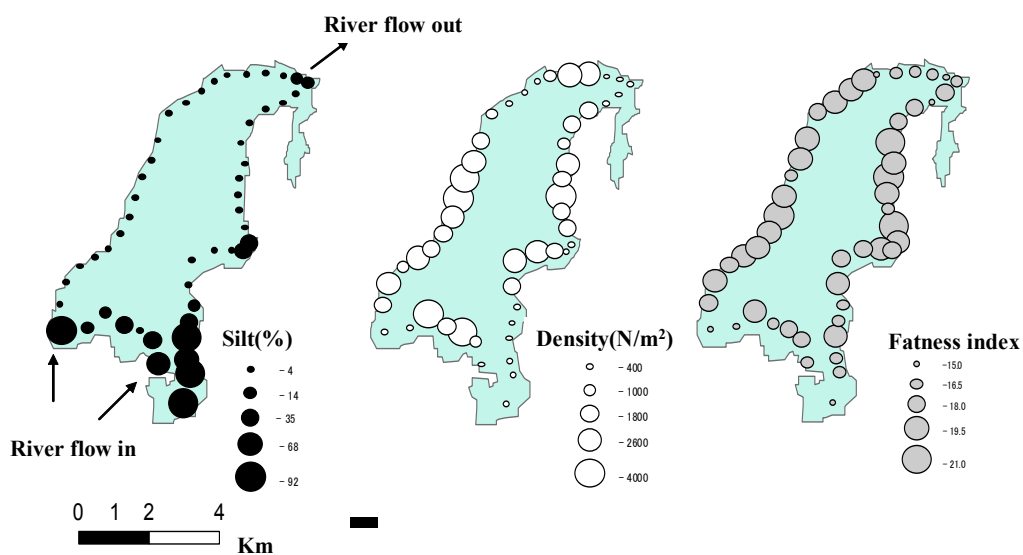

Figure 6: $\quad$ Percent of silty substrate $(<0.063 \mathrm{~mm})(\mathrm{left})$, density $\left(\mathrm{N} / \mathrm{m}^{2}\right)$ (center) and fatness index of $C$. japonica (right) in the Abashiri Lake.

C. japonica specimens were collected at the same sampling stations. Densities and fatness were higher on the western and eastern shores than on the northern and southern shores (Fig.6). There was a negative relationship between bivalve abundance and the percentage of finer particles. We also found a negative relationship between the fatness of $C$. japonica and the percent of fine particles.

\subsection{Land-use and other factors affecting sediments discharge revealed by GIS analysis}

Factors affecting sediment yield were calculated for the eleven tributaries (Table 1). The watershed area was 22.3 to $202.3 \mathrm{~km}^{2}$. The agricultural area 
ranged from 0 to $56.5 \%$ of each watershed, while the forested land occupied between 36.5 and $100 \%$. The percentage of slopes steeper than 20 degrees was smaller for downstream tributaries than for upstream tributaries. Soft rocks dominated western parts of the watershed. Higher densities of faults developed in these tributaries.

The relationships between suspended solid concentration and percentage cover of agricultural land were unclear; the larger agricultural tributaries had lower sediment concentrations in August 2003, whereas forested tributaries, such as $\mathrm{t} 9 \sim \mathrm{t} 11$, had the highest suspended solid concentrations. Slope steepness was not correlated with the particle concentration. The t5 tributary had the steeper slope, but not the highest suspended solid concentrations. Presence of soft rock strongly influenced the suspended solid concentration (tributary t10 showed the highest concentration).

Multiple regression analysis was performed to determine proportional effects of environmental factors on variations in suspended solid concentration. Lithological hardness and the densities of faults (medium) were positively correlated with suspended solid concentrations (Table 2).

Table 1: $\quad$ Environmental variables in each tributary.

\begin{tabular}{|c|c|c|c|c|c|c|c|}
\hline \multirow{2}{*}{ Tributary } & \multirow{2}{*}{$\begin{array}{l}\text { Area } \\
\qquad\left(\mathrm{km}^{2}\right)\end{array}$} & \multicolumn{5}{|c|}{ Environmental variable(\%) } & \multirow{2}{*}{$\begin{array}{c}\text { Highest SS } \\
\text { concentration } \\
(\mathrm{mg} / \mathrm{l})\end{array}$} \\
\hline & & $\begin{array}{l}\text { Agricultural } \\
\text { land (\%) }\end{array}$ & $\begin{array}{c}\text { Forest } \\
\text { coverage }(\%)\end{array}$ & Soft rock (\%) & $\begin{array}{l}\text { Higher density } \\
\text { of faults (\%) }\end{array}$ & $\begin{array}{c}\text { Steep slope } \\
\left(>20^{\circ}\right)(\%)\end{array}$ & \\
\hline $\mathrm{t} 1$ & 126.3 & 56.53 & 36.59 & 10.26 & 0 & 0.08 & 265.15 \\
\hline $\mathrm{t} 2$ & 39.7 & 35.57 & 59.46 & 12.39 & 0 & 3.7 & 377.2 \\
\hline $\mathrm{t} 3$ & 202.3 & 19.75 & 73.21 & 0 & 0 & 12.04 & 258.5 \\
\hline $\mathrm{t} 4$ & 54.6 & 9.7 & 89.49 & 11.59 & 11.63 & 48.63 & 335.05 \\
\hline t5 & 87.9 & 6.57 & 92.6 & 53.04 & 19.73 & 82.08 & 666.25 \\
\hline t6 & 152.2 & 8.25 & 86.81 & 14.87 & 0 & 59.49 & 208.05 \\
\hline $\mathrm{t} 7$ & 75.7 & 13.49 & 85.49 & 58.83 & 0 & 56.39 & 741.4 \\
\hline t8 & 52.5 & 5.79 & 91.02 & 55.07 & 35.37 & 82.35 & 405.25 \\
\hline t9 & 108 & 9.77 & 89.32 & 40.57 & 12.11 & 59.3 & 1499.4 \\
\hline $\mathrm{t} 10$ & 30 & 0.14 & 99.68 & 62.95 & 15.16 & 76 & 1872 \\
\hline $\mathrm{t} 11$ & 22.3 & 0 & 100 & 53.67 & 0 & 54.85 & 704.6 \\
\hline
\end{tabular}

\section{Discussion}

Land use practice usually strongly influences sediment yield (suspended sediment concentration correlates positively with the proportion of agricultural land, and negatively with the proportion of forested land [15]). Our previous study showed that sediment concentrations exceeding $2000 \mathrm{mg} / \mathrm{l}$ were produced in highly agricultural watersheds; the sediment sources were landslide scars resulting from soil compaction by agricultural machinery [11, 13]. However, in the present study, we observed lower suspended yield in larger agricultural tributaries. Instead, suspended sediment concentration was strongly correlated with lithological conditions (Table 2). The western tributaries (where a large portion of watershed is on soft rock) are assumed to be the major source of suspended sediment for the main channels (Fig.4). Furthermore, higher suspended solid discharge may affect sedimentation in Lake Abashiri (Fig.6). 
The lithological characteristics of the watershed are such that land use must be carefully managed, even for forested regions.

In these mountains, numerous landslide scars were observed along channels (Sato unpublished data). These scars resulted from lateral scouring of stream banks during large water discharges; soil wash out can be a serious consequence of this. Other sources of stream sediments may be timber harvesting and logging road construction. The higher densities of logging roads were near St.t9 and t10 tributaries. Roads can affect streams directly by accelerating erosion and sediment loading, by altering channel morphology, and by changing the runoff characteristic of the watershed [5]. In addition, cut branches and trunks are piled along streams, and this debris is easily swept away during downpours. In order to protect land cover, precautionary forest practices should be followed. For instance, although there is no regulation on the cutting of riparian forest, a buffer strip of more than $20 \mathrm{~m}$ wide should be protected. Logging roads should avoid streams and inner valley gorges. The number of stream crossings should be minimized [17]. The exposed soil of cuts and fills should be planted with grass or rapidly growing shrubs. One effective method for decreasing surface water runoff is the installation of ditches and cross-drain culverts along logging roads [9]. Sediment ponds at the end of small catchments may be effective in trapping and reducing suspended matter downstream.

Table 2: $\quad$ Results of multiple regression analysis.

\begin{tabular}{l|rr|r}
\hline \multicolumn{1}{c|}{ Variable } & Un standerdrized coefficient & Probability & $\mathrm{R}^{2}$ \\
& $\mathrm{~B}$ & & \\
\hline Constant & 26763.337 & 0.0573 & \\
Agricultural land (\%) & -279.891 & 0.0621 & \\
Forest coverage (\%) & -266.837 & 0.0522 & 0.801 \\
Steeper slope $<20^{\circ}(\%)$ & -19.366 & 0.422 & $(\mathrm{P}=0.132)$ \\
Soft rock (\%) & 33.933 & 0.0198 & \\
Fault density (medium) (\%) & 95.412 & 0.0475 & \\
Fault density (higher) (\%) & -103.864 & 0.0315 & \\
\hline
\end{tabular}

Suspended sediments have strong effects on aquatic biota [10, 17]. Inorganic turbidity presents a wide range of problems, particularly for filter feeding organisms. The harmful effects on suspension-feeding bivalves include gill tissue fouling, increased pseudofaecal production [18], decline of ingestion rate resulted from reduction of clearance rate [3], depressed growth rates through overloading the gut and gills with inorganic solids [4, 12], reduced metabolic rates and feeding efficiency [1]. Respiration rates are significantly affected by acclimation temperature and turbidity $[2,14])$. Based on these studies, it was likely that fine sediment derived from upstream tributaries had a significant influence on the lake inhabiting bivalve $C$. japonica. The higher suspended solid concentration $(>1600 \mathrm{mg} / \mathrm{l})$ occurred at St. $\mathrm{m} 2$, which was the nearest station upstream from the lake. Concentration declined drastically at St.m1, just downstream from the lake (Fig.4). Hence, most of sediment transported from upstream probably accumulates around the river mouth on the southern shore, 
and the lower density and lower growth of $C$. japonica in that area may be attributable to material produced upstream.

Salinity is a factor controlling distribution of the $C$. japonica [7]. In this study, high salinity considered to be one of negative factor to influence the density and fatness of $C$. japonica on the north shore (Fig.6) where seawater flows in from the Sea of Okhotsk during high tides. Because the frequency of open shells in C. japonica is generally lower in higher salinity conditions

Corbicula sp. contributes significantly to total benthic community respiration [6]. In particular, C. japonica uses organic material derived from terrestrial sources [8]. However, the proportion of organic matter was $<15 \%$ in the sediments deposited around the river mouth, and it is likely that the negative effects of fine inorganic sediments outweigh the positive effects of any organic food source in the sediment. Management of upstream forests to decrease fine inorganic sediments and increase organic content may be important for conservation of fishery resources in the lake represented by C. japonica.

Although concerns for river management have increased recently in this region, a watershed network (a partnership of local residence involving various stakeholders such as fisherman, farmers, and foresters aimed at preserving water quality and regulating land use practice) has not been established in the province of Hokkaido. More detailed data on the influence of land use practice on fish resources will be required for better watershed management.

\section{Acknowledgements}

This study was performed with the cooperation of Marine science center of Abashiri, and Abashiri fisheries cooperation. We would also like to be grateful to Mr Kamada T., Kikuchi T.and Moriwaka H., who were students of Hokkaido Institute of Technology and assisted a field investigation and laboratory analysis.

\section{References}

[1] Aldridge D. W., Payne B. S. \& Miller A. C., The effects of intermittent exposure to suspended solids and turbulence on three species of freshwater mussels, Environ. Pollut. 45, pp. 17-28, 1987.

[2] Alxander J E., Thorp J. H. Jr., and Fell R. D., Turbidity and temperature effects on oxygen consumption in the zebra mussel (Dreissena polymorpha), Can. J. Fish. Aquat. Sci. 51, pp. 179-184, 1994.

[3] Bricelj, V. M. \& Malouf R. E., Influence of algal and suspended sediment concentrations on the feeding physiology of hard clam Mercenaria mercenaria. Mar. Biol. 84, pp. 155-165, 1984.

[4] Bricelj, V. M., Malouf R. E., \& de Quillfeldt C., Growth of juvenile Mercenaria mercenairia and the effect of resuspeded bottom sediments, Marl. Biol., 84, pp. 167-173, 1984.

[5] Furniss M. J., Roelofs T. D., \& Yee C. S., Road construction and maintenance. Influences of forest and rangeland management on salmonid fishes and their habitats, ed. in W. R. Meehan, pp. 292-323, 1991. 
[6] Hakenkamp C. C. \& Palmer M. A., Introduced bivalves in firewater ecosystems: the impact of Corbicula on organic matter dynamics in a sandy stream, Oecologia, 119, pp. 445-451, 1999.

[7] Ishida O., \& Ishii T., Salinity tolerance and regional morphological differences for Corbicula japonica. Fishery culture 19(4), pp.167-182, 1971.

[8] Kasai, A. \& Nakata A., Utilization of terrestrial organic matter by the bivalve Corbicula japonica estimated from stable isotope analysis. Fisheries Science, 71, 151-158, 2005.

[9] Moore G. D., Resource road rehabilitation handbook: Planning and implementation guidelines. Watershed Restoration Technical Circular no. 3. Ministry of environment, lands and Parks and Ministry of Forest. Province of British Columbia, Canada, pp.99, 1994.

[10] Nagasaka, A., Nakajima, M., Yanai, S. \& Nagasaka, Y., Influences of substrate composition on stream habitat and macroinvertebrate communities: a comparative experiment in a forested and an agricultural catchment. Ecology and Civil Engineering, 3, pp. 243-254, 2000 (in Japanese with English abstract).

[11] Nagasaka A., Yanai S., Sato H. \& Hasegawa S., Soil erosion and gully growth associated with cultivation in south-western Hokkaido, Japan. Ecological Engineering 24, pp. 503-508, 2005.

[12] Payne B. S., Lei J., Miller A. C. \& Hubertz E. D., Adaptive variation in palp and gill sizen of zebra mussel (Dreissena polymorpha) and Asian clam (Corbicula fluminea). Can. J. Fish. Aquat. Sci. 52, pp. 1130-1134, 1995.

[13] Sato Hi., Yanai S., Nagasaka Y., Nagasaka A. \& Sato Ha., Influences of land-use on suspended sediment discharge from watersheds emptying into Funka-Bay, south-western Hokkaido, Northern Japan, J. Japan Soc. Hydrol. \& Water Resour., 15, pp. 117-127, 2002 (in Japanese with English abstract).

[14] Summers R. B., Thorp J H., Alexander J. E. \& Fell R. D., Respiratory adjustment of dreissenid mussels (Dreinnena polymorpha and Dereissena bugensis) in response to chronic turbidity, Can. J. Fish. Aquat. Sci., 53, pp. 1626-1631, 1996.

[15] Walling D. E. \& Webb B. W., Water quality 1. Physical characteristics. River Flow and Channel Forms, ed. G. Petts \& P. Calow, Blackwell Science Publishers, pp. 77-101, 1995.

[16] Walling, D. E., Suspended sediment yields in a changing environment. Changing River Channels, ed. A. Gurnell \& G., Petts, John Wiley \& Sons Ltd., 1995.

[17] Waters T. F., Sediment in streams, sources, biological effects and control, American Fisheries Society Monoghraph 7, pp.251, American Fisheries Society, Bethesda, Maryland, 1995.

[18] Way C. M., Hombach D. J., Miller-way C. A., Payne B. S. \& Miller A. C., Dynamics of filter feeding in Corbicula fluminea (Bivalvia: Corbiculidae). Can. J. Zool. 68, pp. 115-120, 1990. 